\title{
Resveratrol attenuates angiotensin II-induced interleukin-6 expression and perivascular fibrosis
}

\author{
Keita Inanaga $^{1}$, Toshihiro Ichiki ${ }^{1,2}$, Hirohide Matsuura ${ }^{1}$, Ryohei Miyazaki ${ }^{1}$, Toru Hashimoto ${ }^{1}$, Kotaro Takeda ${ }^{1,2}$ \\ and Kenji Sunagawa ${ }^{1}$
}

Recent studies have shown that resveratrol (3,5,4'-trihydroxystilbene), a polyphenolic compound found in grapes and red wine, has various beneficial effects on cardiovascular diseases and prolongs the life span of mice fed a high-fat diet. We hypothesized that resveratrol may attenuate vascular inflammatory response induced by angiotensin (Ang) II. We examined the effect of resveratrol on Ang II-induced interleukin (IL)- 6 expression in vascular smooth muscle cells (VSMCs). Resveratrol significantly attenuated Ang II-induced IL- 6 mRNA expression and IL- 6 protein in the supernatant of VSMC in a dose-dependent manner. Resveratrol suppressed the IL- 6 gene promoter activity. Resveratrol inhibited the Ang II-induced CAMP-response element-binding protein and nuclear factor-kappa B activity, which are critical for Ang II-induced IL-6 gene activation. An increase in the serum concentration of IL-6 induced by Ang II infusion was attenuated by an oral administration of resveratrol. Resveratrol also inhibited Ang II-induced hypertension and perivascular fibrosis of the heart. Although hydralazine reduced blood pressure level equal to resveratrol, it did not reduce the Ang II-induced IL- 6 production and perivascular fibrosis. These data suggest that the inhibition of Ang II-induced vascular inflammation and high blood pressure by resveratrol may contribute, at least in part, to the anti-atherogenic effects of resveratrol.

Hypertension Research (2009) 32, 466-471; doi:10.1038/hr.2009.47; published online 17 April 2009

Keywords: angiotensin II; CREB; interleukin-6; NF-kB; resveratrol

\section{INTRODUCTION}

Angiotensin (Ang) II is a main final effector molecule of the reninangiotensin system and plays an important role in the regulation of fluid and electrolyte balance and blood pressure. ${ }^{1}$ Ang II is also involved in cardiac hypertrophy and fibrosis, atherogenesis and renal failure. ${ }^{2}$ Two Ang II receptors, Ang II type-1 receptor and type-2 receptor, have been identified. ${ }^{3}$ Most of the traditional cardiovascular effects of Ang II are mediated by Ang II type-1 receptor. Indeed, Ang II type-1 receptor antagonists are effective in the treatment of not only high blood pressure ${ }^{4}$ but also heart failure, ${ }^{5}$ atherosclerosis ${ }^{6}$ and diabetic nephropathy. ${ }^{7}$

Interleukin (IL)- 6 is a proinflammatory cytokine that induces expression of the C-reactive protein, fibrinogen and production of platelets. ${ }^{8}$ In addition, many reports suggest that IL-6 is a useful biomarker that predicts future cardiovascular events. ${ }^{9,10}$ IL-6 is produced from many cell types, including vascular smooth muscle cells (VSMCs). It was reported that the IL-6 expression in VSMCs is induced by IL- $1,{ }^{11}$ platelet-derived growth factor ${ }^{12}$ and Ang II. ${ }^{13}$ The induction of IL-6 by Ang II is reported to be dependent on the activation of two transcription factors, cAMP-response element-binding (CREB) protein ${ }^{13,14}$ and nuclear factor-kappa B $(\mathrm{NF}-\kappa \mathrm{B}) .{ }^{14}$
Resveratrol (3,5,4'-trihydroxystilbene) is a polyphenolic compound abundant in the skins of grapes and red wine. It has anti-inflammatory, anti-platelet and antioxidant activities. ${ }^{15}$ These properties of resveratrol are believed to be beneficial for the prevention and treatment of cardiovascular diseases. Resveratrol has been shown to extend the life span of a wide variety of species from yeast to mammals. The longevity by resveratrol is, at least in part, mediated by SIRT1, a NAD ${ }^{+}$-dependent histone deacetylase. ${ }^{16}$ Resveratrol is reported to suppress Ang II-induced Akt activation and extracellular signal-regulated protein kinase to a lesser extent. ${ }^{17}$ However, the effect of resveratrol on Ang II-induced cytokine production remains to be determined. We, therefore, examined in this study whether resveratrol inhibits the Ang II-induced IL-6 expression in VSMCs.

\section{MATERIALS AND METHODS}

Materials

Dulbecco's modified Eagle's medium (DMEM) was purchased from GIBCO BRL (Carlsbad, CA, USA). Fetal bovine serum was from JRH Biosciences Inc. (Lenexa, KS, USA). Resveratrol and bovine serum albumin were purchased from Sigma Chemical Co. (St Louis, MO, USA). Ang II was purchased from PEPTIDE Inc. (Osaka, Japan). An enzyme-linked immunosorbent assay

\footnotetext{
${ }^{1}$ Department of Cardiovascular Medicine, Kyushu University Graduate School of Medical Sciences, Fukuoka, Japan and ${ }^{2}$ Department of Advanced Therapeutics for Cardiovascular Diseases, Kyushu University Graduate School of Medical Sciences, Fukuoka, Japan

Correspondence: Dr T Ichiki, Department of Cardiovascular Medicine, Kyushu University Graduate School of Medical Sciences, 3-1-1 Maidashi, Higashiku, 812-8582 Fukuoka, Japan.

E-mail ichiki@cardiol.med.kyushu-u.ac.jp

Received 4 February 2009; revised 4 March 2009; accepted 5 March 2009; published online 17 April 2009
} 
(ELISA) kit for rat IL-6 was purchased from BioSource International (Camarillo, CA, USA). A mouse IL-6 ELISA kit was purchased from R\&D systems (Minneapolis, MN, USA). $\left[\alpha_{-}{ }^{32} \mathrm{P}\right] \mathrm{dCTP}$ and $\left[\gamma^{32} \mathrm{P}\right]$ ATP were purchased from PerkinElmer Life Sciences (Waltham, MA, USA). Other chemical reagents were purchased from Wako Pure Chemicals (Osaka, Japan) unless mentioned specifically.

\section{Cell culture}

Vascular smooth muscle cells were isolated from the thoracic aorta of SpragueDawley rats and maintained in DMEM supplemented with $10 \%$ fetal bovine serum at $37^{\circ} \mathrm{C}$ in a humidified atmosphere of $95 \%$ air- $5 \% \mathrm{CO}_{2}$. Passages between 5 and 15 were used for the experiments. Cells were seeded in $6-\mathrm{cm}$ tissue culture dishes or in 24-well plates, and cultured in DMEM with 10\% fetal bovine serum for 4 days. Then the medium was changed to DMEM supplemented with $0.1 \%$ bovine serum albumin. The cells were cultured for an additional 2 days and stimulated with Ang II.

\section{Northern blot analysis}

Total RNA was prepared by an acid guanidinium-thiocyanate-phenol-chloroform extraction method. Northern blot analysis of IL-6 mRNA was carried out as described earlier. ${ }^{13}$ The hybridized membrane was stripped by boiling in $0.5 \%$ sodium dodecyl sulfate solution and hybridized to a ${ }^{32} \mathrm{P}$-labeled $18 \mathrm{~S}$ ribosomal RNA probe to obtain a reference for the amount of applied RNA. The membrane was then exposed to a KODAK (Rochester, NY, USA) BioMax XAR Film at $-80^{\circ} \mathrm{C}$. Densitometric analysis of IL- 6 mRNA or $18 \mathrm{~S}$ ribosomal RNA was quantified by Image Gauge Software (Version 3.45, Fujifilm, Tokyo, Japan).

\section{Quantification of rat IL-6 by sandwich ELISA}

Vascular smooth muscle cells were stimulated with Ang II $\left(100 \mathrm{nmoll}^{-1}\right)$ for $24 \mathrm{~h}$ in the presence or absence of resveratrol $\left(100 \mu \mathrm{moll}^{-1}\right)$. The supernatant of VSMCs was collected and centrifuged at 12000 r.p.m. for $1 \mathrm{~min}$. The supernatant was stored at $-80^{\circ} \mathrm{C}$ until assay. ELISA for rat IL-6 was carried out with a Cytoscreen ELISA kit (BioSource International), according to the manufacturer's instructions.

\section{Transfection of IL-6 promoter-luciferase fusion DNA construct to VSMC}

Interleukin-6 gene promoter-lusiferase fusion DNA construct was reported earlier. ${ }^{13}$ Confluent VSMCs were split by trypsin/EDTA solution, and $5 \times 10^{5}$ cells were prepared in a 6 -cm tissue culture dish. After $48 \mathrm{~h}, 5 \mu \mathrm{g}$ of IL-6 promoter-luciferase fusion DNA and $2 \mu \mathrm{g}$ of $\beta$-galactosidase gene driven by an SV40 promoter-enhancer sequence were introduced to VSMC by the diethylaminoethyl dextran method according to the manufacturer's instructions (Promega Corporation, Madison, WI, USA). After transfection, the cells were cultured in DMEM with $10 \%$ fetal bovine serum for $24 \mathrm{~h}$, washed twice with phosphate-buffered saline and stimulated with $100 \mathrm{nmoll}^{-1}$ of Ang II for $24 \mathrm{~h}$ with or without resveratrol $\left(100 \mu \mathrm{mol}^{-1}\right)$. The luciferase activity was measured and normalized by $\beta$-galactosidase activity as described earlier. ${ }^{18}$

\section{Preparation of nuclear extracts and gel mobility shift assay}

Nuclear extracts of Ang II-stimulated VSMCs, with or without resveratrol stimulation, were collected as described earlier. ${ }^{18}$ A synthetic DNA probe (NF-kB: CATGTGGGATTTTCCCATGA) was labeled with ${ }^{32} \mathrm{P}$ using $\left[\gamma^{-}{ }^{32} \mathrm{P}\right]$ ATP and T4 polynucleotide kinase, and purified by a Sephadex G-50 column (Roche Applied Science, Indianapolis, IN, USA). The nuclear extracts of $20 \mu \mathrm{g}$ was incubated with $1 \times 10^{5}$ c.p.m. of labeled DNA probe and $2 \mu \mathrm{g}$ of poly $(\mathrm{dI}-\mathrm{dC})$ in a buffer containing $10 \mathrm{mmoll}^{-1}$ Tris- $\mathrm{HCl}$, pH 7.5, $1 \mathrm{mmoll}^{-1}$ EDTA, $4 \%$ glycerol, $100 \mathrm{mmoll}^{-1} \mathrm{NaCl}$, $2.5 \mathrm{mmoll}^{-1}$ DTT and $100 \mathrm{mgl}^{-1}$ bovine serum albumin for $20 \mathrm{~min}$ at room temperature. The samples were then electrophoresed on a $5 \%$ acrylamide/ $0.25 \times$ TBE gel $\left(1 \times \mathrm{TBE} 90 \mathrm{mmoll}^{-1}\right.$ of Tris borate, $2 \mathrm{mmoll}^{-1}$ of EDTA). After electrophoresis, the gels were dried and exposed to an X-ray film at $-80^{\circ} \mathrm{C}$. For supershift assay of NF- $\mathrm{kB}$, an antibody against a p50 subunit of NF- $\mathrm{kB}(0.5 \mu \mathrm{g}$, Santa Cruz Biotechnology, Santa Cruz, CA, USA) or nonimmune mouse IgG $(0.5 \mu \mathrm{g}$, Invitrogen Corp., Carlsbad, CA, USA) was added to the binding reaction.

\section{Western blot analysis}

Western blot analysis of phosphorylated (p-) CREB and total CREB was carried out as described earlier. ${ }^{19}$ The specific band was scanned with an imaging analyzer. The phosphorylation level of CREB was indicated as a ratio of p-CREB to CREB.

\section{Animal experiment}

All procedures were approved by the institutional animal use and care committee, and were conducted in conformity with institutional guidelines. At 9-weeks-old, C57/B6 mice were purchased from Kyudo Co. Ltd (Saga, Japan). Resveratrol was suspended in water at $0.1 \mathrm{mg} \mathrm{ml}^{-1}$, and administered ad libitum. The estimated dose of orally ingested resveratrol was $10 \mathrm{mg}$ per $\mathrm{kg}$ per day. In the Ang II group, $490 \mathrm{ng}$ per min per kg of Ang II was administered intraperitoneally through an osmotic mini-pump (Alzet, Cupertino, CA, USA). Another group received hydralazine $\left(250 \mathrm{mgl}^{-1}\right.$ in drinking water: estimated uptake was $40 \mathrm{mg}$ per $\mathrm{kg}$ per day). Blood pressure (BP) and heart rate were measured using the tail-cuff method (UR-5000, UEDA, Ueda Industries Co., Tokyo, Japan). At 2 weeks, the mice were killed using pentobarbital anesthesia. Blood sample was collected from the inferior vena cava. To coagulate the blood, the samples were left at room temperature for 2 hours, and then centrifuged for $20 \mathrm{~min}$ at $3000 \mathrm{~g}$. The serum was subjected to IL-6 measurement. At 4 weeks, the heart and aorta were removed and embedded in paraffin, and the tissue slices were stained with Masson-trichrome solutions and hematoxylin/eosin, respectively. The sections were scanned using a light microscope. The area of perivascular fibrosis was measured by planimetry. The extent of perivascular fibrosis of the coronary arteries was evaluated by the ratio of the perivascular fibrosis area to the total vascular area. ${ }^{20}$

\section{Statistical analysis}

Statistical analysis was carried out with one-way ANOVA and Fisher's test, if appropriate. Data are shown as mean \pm s.e.m. $P<0.05$ was considered to be statistically significant.

\section{RESULTS}

Resveratrol attenuates Ang II-induced IL-6 expression in rat VSMC Vascular smooth muscle cells were incubated with resveratrol $\left(100 \mu \mathrm{moll}^{-1}\right)$ for varying time periods, and stimulated with Ang II $\left(100 \mathrm{nmoll}^{-1}\right)$ for $30 \mathrm{~min}$. The expression level of IL-6 mRNA was determined by northern blot analysis. The expression level of IL-6 mRNA was significantly reduced by preincubation with resveratrol for 3 and $6 \mathrm{~h}$ (data not shown). Incubation with varying concentrations of resveratrol for $3 \mathrm{~h}$ resulted in an attenuation of the Ang II-induced IL-6 mRNA expression in a dose-dependent manner (Figure 1a). Resveratrol attenuated Ang II-induced IL-6 production in the medium in a dose-dependent manner (Figure 1b).

\section{Resveratrol attenuates IL-6 gene promoter activity}

Next, we examined the effect of resveratrol on IL-6 gene promoter activity. Resveratrol inhibited the Ang II-induced IL-6 gene promoter activity (Figure 2a). A recent study showed that CREB and NF- $\kappa B$ were critical for the induction of IL- 6 by Ang II. ${ }^{14} \mathrm{We}$, therefore, examined the effect of resveratrol on CREB and on NF- $\kappa B$ activity. Western blot analysis showed that resveratrol inhibited Ang II-induced phosphorylation of CREB at serine133, which is a critical marker of activation (Figure $2 b$ ). Gel mobility shift assay showed that resveratrol also inhibited Ang II-induced NF- $\kappa$ B DNA binding (Figure 2c). The supershift assay showed that the band was shifted by an addition of antibody against a p50 subunit of NF- $\kappa \mathrm{B}$ but not by nonimmune IgG, confirming that the band of gel mobility shift assay involved a p50 subunit of NF- $\kappa \mathrm{B}$.

\section{Resveratrol attenuates Ang II-induced increase in serum IL-6 concentration, blood pressure and perivascular fibrosis of the heart in mice}

We examined whether resveratrol affects Ang II-induced IL-6 production in vivo. BP was elevated in the Ang II group. However, BP levels of resveratrol and hydralazine groups were not significantly different from that of the control group (Table 1). The serum IL-6 level was significantly increased by Ang II. The Ang II-induced increase in the 
a

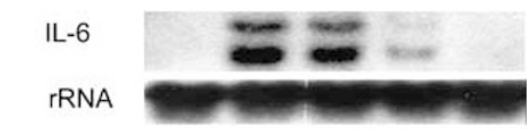

$(\%)$

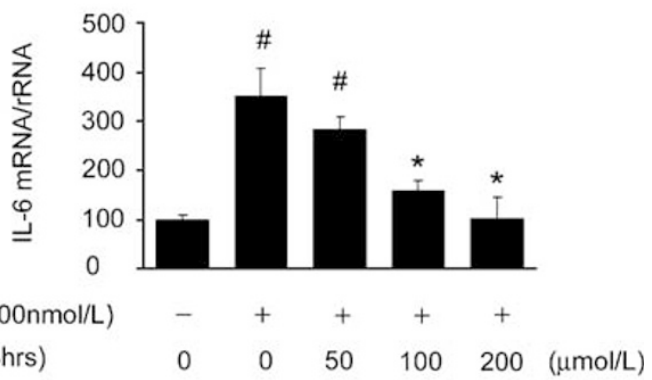

b

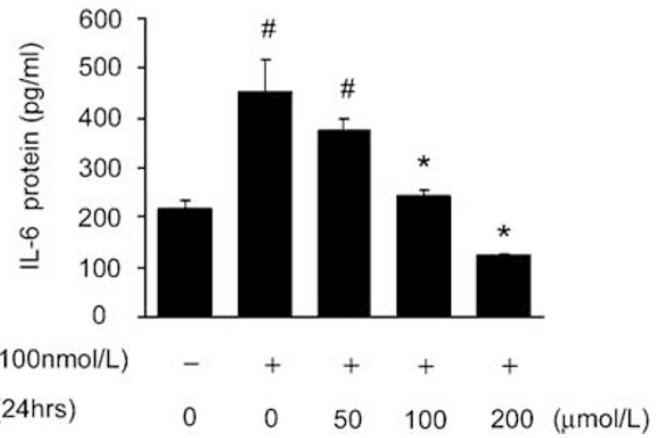

Figure 1 Angiotensin II-induced expression of IL- 6 mRNA and protein in cultured VSMCs was attenuated by resveratrol. (a) Incubation with varying concentrations of resveratrol for $3 \mathrm{~h}$ resulted in a dose-dependent attenuation of angiotensin II-induced IL-6 mRNA expression ( $n=4)$. Total RNA was isolated, and the expressions of IL-6 mRNA and 18s rRNA were determined by northern blot analysis. (b) Resveratrol attenuated angiotensin II-induced IL-6 production in the culture medium in a dose-dependent manner. VSMCs were stimulated with Ang II $(100 \mathrm{nmol} / \mathrm{l})$ for $24 \mathrm{~h}$ without or with the indicated dose of resveratrol. $(n=4)$. ${ }^{\prime} P<0.05$ vs. control, ${ }^{*} P<0.05$ vs. All. All: angiotensin II, RV: resveratrol.

serum IL-6 level was attenuated by resveratrol but not by hydralazine (Figure 3a). As hydralazine reduced blood pressure level equal to resveratrol, it is suggested that a resveratrol-induced IL-6 suppression is independent of a BP lowering effect.

Perivascular fibrosis of the small coronary artery of the heart was examined at 4 weeks. Perivascular fibrosis was increased by Ang II infusion, which was inhibited by resveratrol treatment but not by hydralazine (Figure 3b). Medial thickness of the aorta was slightly increased by Ang II. However, the increase was not statistically significant and we did not observe a significant effect of resveratrol either (data not show).

\section{DISCUSSION}

In this study, we showed that resveratrol inhibited Ang II-induced IL-6 expression both in vitro and in vivo. The inhibition of IL-6 production by resveratrol may be because of the inhibition of CREB and NF- $\kappa \mathrm{B}$, which play an important role in IL-6 induction by Ang II. ${ }^{13,14}$ The in vivo study showed that resveratrol also inhibited Ang II-induced hypertension, IL-6 production and perivascular fibrosis of the heart. However, a suppression of Ang II-induced hypertension by hydralazine did not affect the increase in serum IL-6 level and perivascular fibrosis of the heart, suggesting that the suppression of
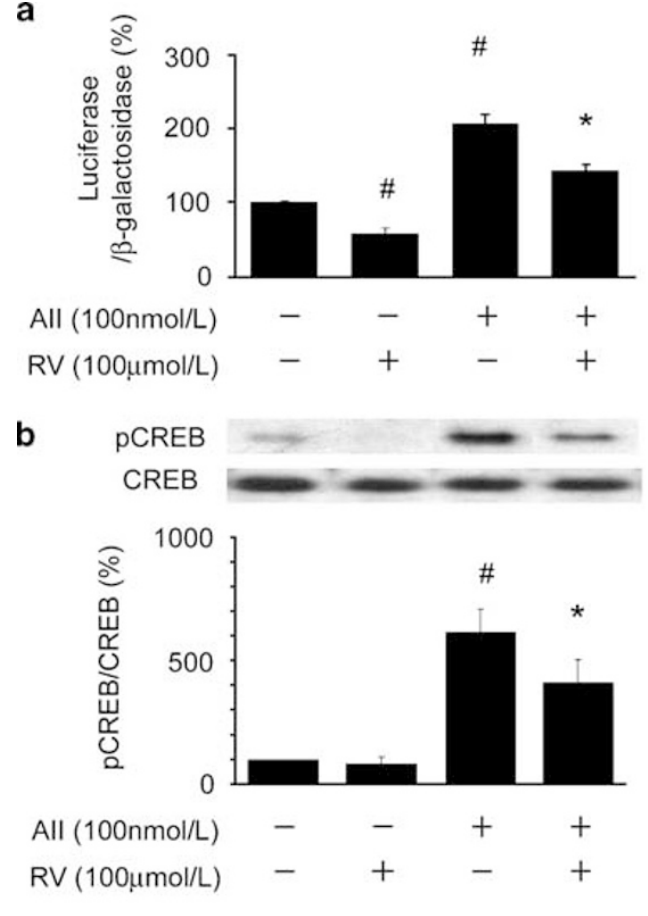

C

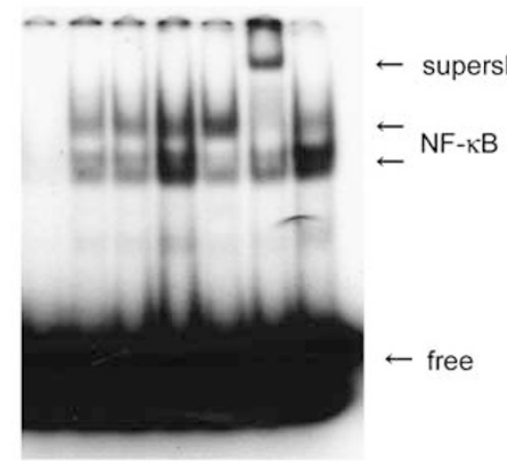

$$
\begin{array}{cl}
\text { All }(100 \mathrm{nmol} / \mathrm{L}) & ---++++ \\
\mathrm{RV}(100 \mu \mathrm{mol} / \mathrm{L}) & --+-+-- \\
\text { Competitor } & +---- \\
\mathrm{NF}-\kappa \mathrm{B} \text { antibody } & -----+- \\
\text { control lgG } & ------+
\end{array}
$$

Figure 2 Effect of resveratrol on angiotensin II-induced IL-6 gene promoter activity, phosphorylation of CREB and activation of NF-KB. (a) Resveratrol inhibited angiotensin II-induced IL-6 gene promoter activity. The luciferase construct was introduced to VSMCs, and the VSMCs were stimulated with angiotensin II $\left(100 \mathrm{nmoll}^{-1}\right)$ for $24 \mathrm{~h}$ with or without resveratrol. The bar graphs indicate luciferase activity normalized by the $\beta$-galactosidase activity $(n=4) .{ }^{\#} P<0.05$ vs. control, ${ }^{*} P<0.05$ vs. All. All: angiotensin II, RV: resveratrol. (b) Resveratrol attenuated angiotensin II-induced phosphorylation of CREB. Phosphorylation of CREB was detected by western blot analysis using a phospho-specific CREB antibody. The ratio of phosphorylated CREB to total CREB is shown as the relative fold increase compared with that in unstimulated cells $(n=4)$. The values are expressed as the mean \pm s.e.m. ${ }^{\#} P<0.05$ vs. control, ${ }^{*} P<0.05$ vs. All. All: angiotensin II, RV: resveratrol. (c) Gel mobility shift assay showed that resveratrol also inhibited angiotensin II-induced NF-KB activity. VSMCs were stimulated with angiotensin II $\left(100 \mathrm{nmoll}^{-1}\right)$ for $30 \mathrm{~min}$ with or without resveratrol $\left(100 \mu \mathrm{moll}^{-1}\right)$ and nuclear extracts were prepared. Fifty times molar excess of unlabeled wild-type probe competitor was added to the reaction mixture (competitor). For super shift assay, an antibody against p50 subunit of NF-KB or non-immune mouse IgG was added to the reaction mixture. The same results were obtained in other independent experiments $(n=4)$. All: angiotensin II, RV: resveratrol. 
Table 1 Body weight, heart rate and blood pressure of mice infused with angiotensin II

\begin{tabular}{|c|c|c|c|c|c|c|}
\hline & \multicolumn{3}{|c|}{2 weeks } & \multicolumn{3}{|c|}{4 weeks } \\
\hline & $B W(g)$ & $H R$ (b.p.m.) & $S B P(m m H g)$ & $B W(g)$ & $H R$ (b.p.m.) & $S B P(m m H g)$ \\
\hline Resveratrol & $24.9 \pm 0.3$ & $526 \pm 18$ & $97 \pm 4$ & $27.8 \pm 0.7$ & $572 \pm 29$ & $107 \pm 5$ \\
\hline Ang II & $25.3 \pm 1.0$ & $586 \pm 16$ & $129 \pm 5^{*}$ & $26.9 \pm 0.5$ & $611 \pm 25$ & $121 \pm 6^{*}$ \\
\hline Ang II+resveratrol & $25.0 \pm 0.7$ & $564 \pm 22$ & $99 \pm 2 * *$ & $27.3 \pm 0.4$ & $579 \pm 28$ & $106 \pm 3^{* *}$ \\
\hline
\end{tabular}

Abbreviations: BW, body weight; HR, heart rate; SBP, systolic blood pressure. Values are expressed means \pm s.e.m., $n=5$.

${ }^{*} P<0.01$ vs. control, ${ }^{* *} P<0.01$ Ang II.
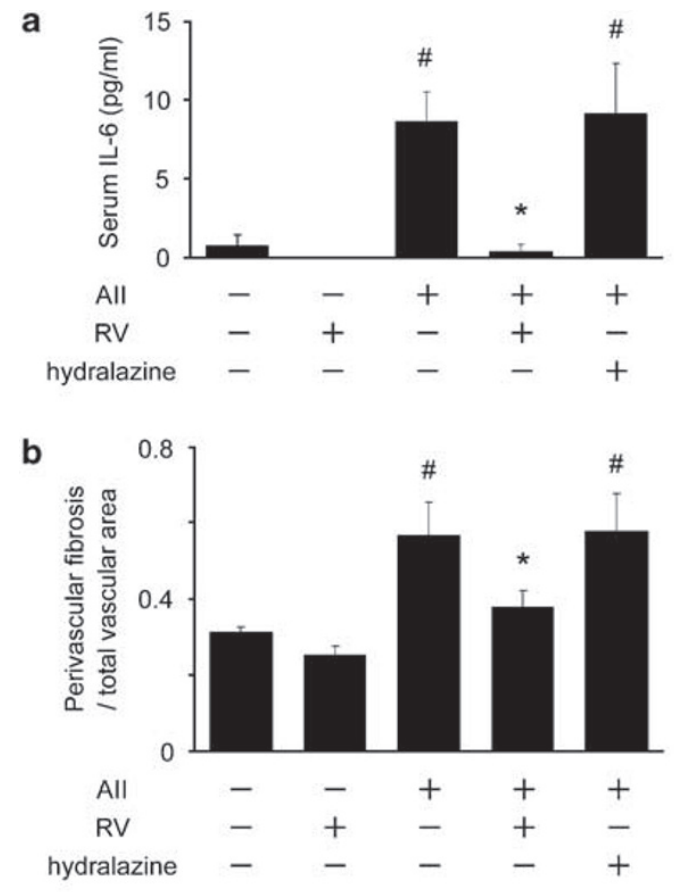

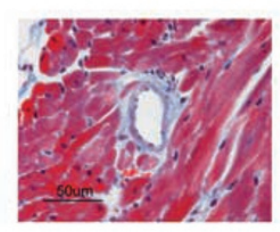

Control

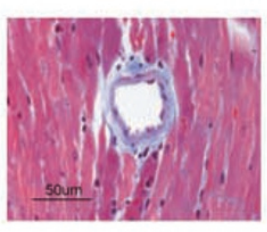

RV

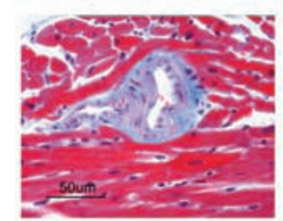

All

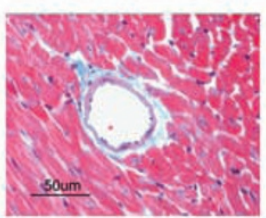

All + RV

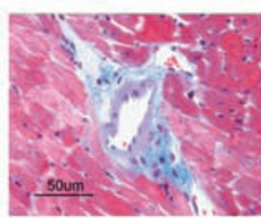

All + hyd
Figure 3 Resveratrol attenuated angiotensin II-induced IL-6 production and perivascular fibrosis in mice. (a) Angiotensin II was administered intraperitoneally through an osmotic mini-pump. Resveratrol was administered ad libitum in drinking water. Hydralazine was administered through drinking water. After 2 weeks of administration, serum IL-6 was measured using ELISA. $(n=5){ }^{\#} P<0.05$ vs. control, ${ }^{*} P<0.05$ vs. All. All: angiotensin II, RV: resveratrol. (b) At 4 weeks, the mice were killed and perivascular fibrosis of the heart was examined. Angiotensin II significantly increased perivascular fibrosis of the small coronary artery. Resveratrol, but not hydralazine, inhibited the angiotensin II-induced perivascular fibrosis. $n=5$. ${ }^{\#} P<0.05$ vs. control, ${ }^{*} P<0.05$ vs. All. All: angiotensin II, RV: resveratrol.
IL-6 production and perivascular fibrosis of the heart by resveratrol was not because of the reduction of BP.

It has been reported that resveratrol has an antioxidant effect. ${ }^{15}$ As Ang II activates NADPH oxidase in VSMCs, and reactive oxygen species play an important role in Ang II signaling, ${ }^{21}$ it is reasonable that resveratrol inhibits Ang II signaling. However, little is known about the role of resveratrol in the modulation of Ang II-induced inflammatory response in blood vessel. It was reported that resveratrol inhibited Ang II-induced endothelin-1 expression and proliferation of VSMCs through a suppression of AP1 activity. ${ }^{22}$ In this study, we showed that Ang II-induced activation of CREB and NF- $\kappa B$, which is involved in IL-6 induction, was inhibited by resveratrol. It was already reported that resveratrol inhibited NF- $\kappa \mathrm{B}$ activity. ${ }^{23}$ However, this is the first report showing the inhibition of CREB activation by resveratrol. It was reported earlier that CREB was activated by hydrogen peroxide. ${ }^{24}$ Therefore, the antioxidative effect of resveratrol may play a role in the inhibition of Ang II-induced CREB phosphorylation. On the contrary, Das et al. ${ }^{25}$ reported that resveratrol activated CREB through the adenosine A3 receptor in an ischemia-reperfusion injury model of a rat heart. The reason for this discrepancy is not clear at this point and requires further study.

Although an inhibition of Ang II-induced hypertension by crude extracts of red wine polyphenol was reported in rat, ${ }^{26}$ the effect of resveratrol on Ang II-induced hypertension remains to be determined. We clearly showed that resveratrol inhibited Ang II-induced hypertension. In addition, it is noteworthy that the effect of resveratrol on Ang II-induced cytokine production in vivo has not been reported. We clearly showed that the serum IL-6 level in Ang II-infused mice was significantly suppressed by resveratrol. However, the major source of serum IL-6 induced by Ang II infusion is not clear at this point. As blood vessel is present in the whole body, it may be possible that IL-6 released from VSMC contributes to the serum IL-6 level to some extent. It is also possible that IL-6 from VSMC causes a local inflammatory response in the blood vessel rather than cause systemic effects.

The role of IL- 6 in the development and progression of atherogenesis is controversial. IL-6 is well known to induce expression of the C-reactive protein, which is a prognostic marker of atherosclerotic cardiovascular diseases. ${ }^{27}$ IL- 6 also stimulates the proliferation of VSMCs. ${ }^{28}$ These data suggest that IL-6 from blood vessel may be involved in a local inflammatory response that may accelerate atherogenesis. In contrast, the genetic deficiency of IL-6 in apolipoprotein E knockout mice showed an enhancement of atherogenesis in spite of decreased macrophage infiltration to the atherosclerotic lesion. ${ }^{29}$ The double knockout mice showed an increase in the very low-density lipoprotein and the low-density lipoprotein level, which may explain the enhanced atherogenesis in these mice and suggest that the role of 
IL-6 in lipid metabolism may be atheroprotective. Therefore, further study is needed to determine the role of locally produced IL- 6 in the development of vascular lesion formation.

In contrast to the experimental studies, the results of most of the clinical studies are consistent and suggest that plasma IL-6 level is a useful biomarker predicting future cardiovascular events ${ }^{9,10}$ and is associated with cardiovascular pathophysiology. Naya et al. ${ }^{30}$ showed that an increase in the plasma IL-6 level was associated with coronary endothelial dysfunction in patients with hypertension. In addition, telmisartan, an Ang II type-1 receptor blocker, was more effective than was amlodipine in reducing plasma IL-6 and matrix metalloproteinase- 9 , which was associated with a reduction of serum creatinine and proteinuria. $^{31}$ Therefore, IL-6 may be a critical cytokine linking inflammatory response to the development of coronary atherosclerosis as well as to renal diseases.

Although a controversy still exists in terms of the role of IL-6 in atherogenesis, resveratrol itself was reported to attenuate atherogenesis in apolipoprotein $\mathrm{E}$ knockout mice without a significant change in the blood lipid profile, ${ }^{32}$ which may indicate the therapeutic or preventive implication of resveratrol in atherosclerotic cardiovascular diseases. Our study suggests that this atheroprotective effect of resveratrol may involve the inhibition of the Ang II function and the resultant suppression of IL-6 production. However, it seems to be difficult to take a sufficient amount of resveratrol from red wine in which the average resveratrol concentration is $5 \mathrm{mgl}^{-1} \cdot{ }^{33,34}$ It is estimated that peak serum resveratrol concentration after taking two glasses of red wine may reach $\sim 180 \mathrm{nmoll}^{-1},{ }^{35}$ which is much lower than the dose we used in this study. Moreover, it goes without saying that taking a large amount of red wine is not recommended because of the possible detrimental effect of alcohol. But, when purified resveratrol at $100 \mathrm{mg} \mathrm{kg}^{-1}$ body weight is taken, the peak serum concentration of resveratrol is estimated at $680 \mu \mathrm{moll}^{-1}$. This estimation may make the dose we used in this study clinically relevant. In addition, it has been reported that resveratrol at a lower concentration between 0.1 and $10 \mu \mathrm{mol}^{-1}$ has beneficial effects on the cardiovascular system, such as an inhibition of TNF $\alpha$-induced NF- $\kappa B$ activation ${ }^{36}$ and an increase in nitric oxide release, ${ }^{37}$ suggesting that two glasses of red wine may also be beneficial. The level of resveratrol found in food varies greatly. In grapes, resveratrol is found primarily in the skin; dry grape skin contains about $24 \mathrm{\mu gg}^{-1}$ of resveratrol. ${ }^{38}$ Other foods such as boiled peanut contains resveratrol of $5.1{\mu \mathrm{gg}^{-1}, 39,40}$ red grape juice contains $0.5 \mathrm{mg}^{-1}$ in average $\mathrm{e}^{41}$ and blueberries $32 \mathrm{ng} \mathrm{g}^{-1}$. ${ }^{42}$ Daily consumption of these foods in combination may protect against cardiovascular diseases to some extent.

In summary, we showed in this study that resveratrol inhibited Ang II-induced IL-6 production both in vitro and in vivo through the inhibition of NF- $\mathrm{KB}$ and CREB. Resveratrol also inhibited Ang IIinduced hypertension and perivascular fibrosis of the heart. These effects may contribute to an inhibition of vascular inflammation leading to the progression of atherosclerosis.

\section{ACKNOWLEDGEMENTS}

This study was supported in part by Grants-in-aid for Scientific Research from the Ministry of Education, Culture, Sports, Science and Technology of Japan (19590867) and by the Kimura Foundation Research Grant 2007 to TI

1 Goodfriend TL, Elliott ME, Catt KJ. Angiotensin receptors and their antagonists. N Engl J Med 1996; 334: 1649-1654.
2 Wright JW, Mizutani S, Harding JW. Pathways involved in the transition from hypertension to hypertrophy to heart failure. Treatment strategies. Heart Fail Rev 2008; 13: 367-375.

3 de Gasparo M, Catt KJ, Inagami T, Wright JW, Unger T. International union of pharmacology. XXIII. The angiotensin II receptors. Pharmacol Rev 2000; 52: 415-472.

4 Burnier M, Brunner HR. Angiotensin II receptor antagonists-antihypertensive agents. Expert Opin Investig Drugs 1997; 6: 489-500.

5 Cohn JN, Tognoni G. A randomized trial of the angiotensin-receptor blocker valsartan in chronic heart failure. N Engl J Med 2001; 345: 1667-1675.

6 Johnstone MT, Perez AS, Nasser I, Stewart R, Vaidya A, AI Ammary F, Schmidt B, Horowitz G, Dolgoff J, Hamilton J, Quist WC. Angiotensin receptor blockade with candesartan attenuates atherosclerosis, plaque disruption, and macrophage accumulation within the plaque in a rabbit model. Circulation 2004; 110: 2060-2065.

7 Brenner BM, Cooper ME, de Zeeuw D, Keane WF, Mitch WE, Parving HH, Remuzzi G, Snapinn SM, Zhang Z, Shahinfar S. Effects of losartan on renal and cardiovascular outcomes in patients with type 2 diabetes and nephropathy. N Eng/ J Med 2001; 345: 861-869.

8 Yudkin JS, Kumari M, Humphries SE, Mohamed-Ali V. Inflammation, obesity, stress and coronary heart disease: is interleukin-6 the link? Atherosclerosis 2000; 148: 209-214.

9 Lobbes MB, Lutgens E, Heeneman S, Cleutjens KB, Kooi ME, van Engelshoven JM, Daemen MJ, Nelemans PJ. Is there more than C-reactive protein and fibrinogen? The prognostic value of soluble CD40 ligand, interleukin-6 and oxidized low-density lipoprotein with respect to coronary and cerebral vascular disease. Atherosclerosis 2006; 187: 18-25.

10 Luc G, Bard JM, Juhan-Vague I, Ferrieres J, Evans A, Amouyel P, Arveiler D, Fruchart JC, Ducimetiere P. C-reactive protein, interleukin-6, and fibrinogen as predictors of coronary heart disease: the PRIME Study. Arterioscler Thromb Vasc Biol 2003; 23 : 1255-1261.

11 Beasley D. Phorbol ester and interleukin-1 induce interleukin-6 gene expression in vascular smooth muscle cells via independent pathways. J Cardiovasc Pharmacol 1997; 29: 323-330.

12 Liu Z, Dronadula N, Rao GN. A novel role for nuclear factor of activated T cells in receptor tyrosine kinase and $\mathrm{G}$ protein-coupled receptor agonist-induced vascular smooth muscle cell motility. J Biol Chem 2004; 279: 41218-41226.

13 Funakoshi $Y$, Ichiki T, Ito K, Takeshita A. Induction of interleukin- 6 expression by angiotensin II in rat vascular smooth muscle cells. Hypertension 1999; 34: 118-125.

14 Sahar S, Reddy MA, Wong C, Meng L, Wang M, Natarajan R. Cooperation of SRC-1 and p300 with NF-kappaB and CREB in angiotensin II-induced IL-6 expression in vascular smooth muscle cells. Arterioscler Thromb Vasc Biol 2007; 27: 1528-1534.

15 Delmas D, Jannin B, Latruffe N. Resveratrol: preventing properties against vascular alterations and ageing. Mol Nutr Food Res 2005; 49: 377-395.

16 Howitz KT, Bitterman KJ, Cohen HY, Lamming DW, Lavu S, Wood JG, Zipkin RE, Chung P, Kisielewski A, Zhang LL, Scherer B, Sinclair DA. Small molecule activators of sirtuins extend Saccharomyces cerevisiae lifespan. Nature 2003; 425: 191-196.

17 Haider UG, Sorescu D, Griendling KK, Vollmar AM, Dirsch VM. Resveratrol suppresses angiotensin II-induced Akt/protein kinase B and p70 S6 kinase phosphorylation and subsequent hypertrophy in rat aortic smooth muscle cells. Mol Pharmacol 2002; 62: 772-777.

18 Miyazaki R, Ichiki T, Hashimoto T, Inanaga K, Imayama I, Sadoshima J, Sunagawa K. SIRT1, a longevity gene, downregulates angiotensin II type 1 receptor expression in vascular smooth muscle cells. Arterioscler Thromb Vasc Biol 2008; 28: 1263-1269.

19 Funakoshi Y, Ichiki T, Takeda K, Tokuno T, lino N, Takeshita A. Critical role of cAMPresponse element-binding protein for angiotensin II-induced hypertrophy of vascular smooth muscle cells. J Biol Chem 2002; 277: 18710-18717.

20 Suda O, Tsutsui M, Morishita T, Tanimoto A, Horiuchi M, Tasaki H, Huang PL, Sasaguri $\mathrm{Y}$, Yanagihara N, Nakashima Y. Long-term treatment with N(omega)-nitro-L-arginine methyl ester causes arteriosclerotic coronary lesions in endothelial nitric oxide synthase-deficient mice. Circulation 2002; 106: 1729-1735.

21 Harrison D, Griendling KK, Landmesser U, Hornig B, Drexler H. Role of oxidative stress in atherosclerosis. Am J Cardiol 2003; 91: 7A-11A.

22 Chao HH, Juan SH, Liu JC, Yang HY, Yang E, Cheng TH, Shyu KG. Resveratrol inhibits angiotensin II-induced endothelin-1 gene expression and subsequent proliferation in rat aortic smooth muscle cells. Eur J Pharmacol 2005; 515: 1-9.

23 Manna SK, Mukhopadhyay A, Aggarwal BB. Resveratrol suppresses TNF-induced activation of nuclear transcription factors NF-kappa B, activator protein-1, and apoptosis: potential role of reactive oxygen intermediates and lipid peroxidation. J Immunol 2000; 164: 6509-6519.

24 Ichiki T, Tokunou T, Fukuyama K, lino N, Masuda S, Takeshita A. Cyclic AMP response element-binding protein mediates reactive oxygen species-induced c-fos expression. Hypertension 2003; 42: 177-183.

25 Das S, Tosaki A, Bagchi D, Maulik N, Das DK. Resveratrol-mediated activation of cAMP response element-binding protein through adenosine $\mathrm{A} 3$ receptor by Akt-dependent and -independent pathways. J Pharmacol Exp Ther 2005; 314: 762-769.

26 Sarr M, Chataigneau M, Martins S, Schott C, El Bedoui J, Oak MH, Muller B, Chataigneau T, Schini-Kerth VB. Red wine polyphenols prevent angiotensin II-induced hypertension and endothelial dysfunction in rats: role of NADPH oxidase. Cardiovasc Res 2006; 71: 794-802.

27 Ridker PM, Rifai N, Rose L, Buring JE, Cook NR. Comparison of C-reactive protein and low-density lipoprotein cholesterol levels in the prediction of first cardiovascular events. N Engl J Med 2002; 347: 1557-1565.

28 Yao JS, Zhai W, Fan Y, Lawton MT, Barbaro NM, Young WL, Yang GY. Interleukin-6 upregulates expression of KDR and stimulates proliferation of human cerebrovascular smooth muscle cells. J Cereb Blood Flow Metab 2007; 27: 510-520. 
29 Schieffer B, Selle T, Hilfiker A, Hilfiker-Kleiner D, Grote K, Tietge UJ, Trautwein C, Luchtefeld M, Schmittkamp C, Heeneman S, Daemen MJ, Drexler H. Impact of interleukin- 6 on plaque development and morphology in experimental atherosclerosis. Circulation 2004; 110: 3493-3500

30 Naya M, Tsukamoto T, Morita K, Katoh C, Furumoto T, Fujii S, Tamaki N, Tsutsui H. Plasma interleukin- 6 and tumor necrosis factor-alpha can predict coronary endothelial dysfunction in hypertensive patients. Hypertens Res 2007; 30: 541-548.

31 Nakamura T, Inoue T, Suzuki T, Kawagoe Y, Ueda Y, Koide H, Node K. Comparison of renal and vascular protective effects between telmisartan and amlodipine in hypertensive patients with chronic kidney disease with mild renal insufficiency. Hypertens Res 2008; 31: 841-850.

32 Fukao H, Ijiri Y, Miura M, Hashimoto M, Yamashita T, Fukunaga C, Oiwa K, Kawai Y, Suwa M, Yamamoto J. Effect of trans-resveratrol on the thrombogenicity and atherogenicity in apolipoprotein E-deficient and low-density lipoprotein receptor-deficient mice. Blood Coagul Fibrinolysis 2004; 15: 441-446.

33 Gescher AJ, Steward WP. Relationship between mechanisms, bioavailibility, and preclinical chemopreventive efficacy of resveratrol: a conundrum. Cancer Epidemio/ Biomarkers Prev 2003; 12: 953-957.

34 Pervaiz S. Resveratrol: from grapevines to mammalian biology. FASEB J 2003; 17: 1975-1985.
35 Baur JA, Sinclair DA. Therapeutic potential of resveratrol: the in vivo evidence. Nat Rev Drug Discov 2006; 5: 493-506.

36 Csiszar A, Smith K, Labinskyy N, Orosz Z, Rivera A, Ungvari Z. Resveratrol attenuates TNF-alpha-induced activation of coronary arterial endothelial cells: role of NF-kappaB inhibition. Am J Physiol Heart Circ Physiol 2006; 291: H1694-H1699.

37 Leikert JF, Rathel TR, Wohlfart P, Cheynier V, Vollmar AM, Dirsch VM. Red wine polyphenols enhance endothelial nitric oxide synthase expression and subsequent nitric oxide release from endothelial cells. Circulation 2002; 106: 1614-1617.

38 Romero-Perez AI, Lamuela-Raventos RM, Andres-Lacueva C, de La Torre-Boronat MC. Method for the quantitative extraction of resveratrol and piceid isomers in grape berry skins. Effect of powdery mildew on the stilbene content. J Agric Food Chem 2001; 49: 210-215.

39 Burns J, Yokota T, Ashihara H, Lean ME, Crozier A. Plant foods and herbal sources of resveratrol. J Agric Food Chem 2002; 50: 3337-3340.

40 Sobolev VS, Cole RJ. Trans-resveratrol content in commercial peanuts and peanut products. J Agric Food Chem 1999; 47: 1435-1439.

41 Romero-Perez Al, Ibern-Gomez M, Lamuela-Raventos RM, de La Torre-Boronat MC. Piceid, the major resveratrol derivative in grape juices. J Agric Food Chem 1999; 47: 1533-1536.

42 Lyons MM, Yu C, Toma RB, Cho SY, Reiboldt W, Lee J, van Breemen RB. Resveratrol in raw and baked blueberries and bilberries. J Agric Food Chem 2003; 51: 5867-5870. 